\title{
Silibinin Attenuates Mast Cell-Mediated Anaphylaxis-Like Reactions
}

\author{
Yun $\mathrm{Ho}_{\mathrm{CHOI}}{ }^{a}$ and Guang Hai YAN${ }^{*, b}$ \\ ${ }^{a}$ Department of Anatomy, Chonbuk National University Medical School; Jeonju, Jeonbuk 561-756, Republic of Korea; \\ and ${ }^{b}$ Department of Anatomy and Histology and Embryology, Yanbian University School of Basic Medical Sciences; 1829 \\ JuZi Street, YanJi City 133000, Jilin, P. R. China. \\ Received December 10, 2008; accepted February 19, 2009; published online February 23, 2009
}

Silibinin is known to have hepatoprotective, anti-carcinogenic and anti-inflammatory effects. However, roles of silibinin in the immediate-type allergic reactions (anaphylaxis) have not fully been investigated. In the present study, we have demonstrated that silibinin attenuated mast cell-mediated anaphylaxis-like reactions involved in allergic diseases. Oral administration of silibinin inhibited compound 48/80-induced passive cutaneous anaphylaxis-like reaction in mice. Silibinin also attenuated anti-dinitrophenyl (DNP) immunoglobulin (Ig) E-mediated passive systemic and cutaneous anaphylaxis. Silibinin had no cytotoxicity on rat peritoneal mast cells (RPMC). Silibinin dose-dependently reduced histamine release from RPMC activated by compound 48/80 or anti-DNP IgE. Moreover, silibinin inhibited the secretion of pro-inflammatory cytokines, such as tumor necrosis factor- $\alpha$ and interleukin-6 in RPMC. Pretreatment of silibinin suppressed the antigen-stimulated calcium uptake and activation of nuclear factor-kappa B (NF- $\mathrm{KB})$ in RPMC. Furthermore, silibinin increased the intracellular cAMP level. Increased CAMP, decreased calcium uptake and suppressed NF- $\kappa$ B activity might be involved in the inhibitory effect of silibinin on the secretory response. Our findings provide possibility that silibinin may serve as an effective therapeutic agent for allergic diseases.

Key words mast cell; anaphylaxis-like reaction; silibinin; histamine; calcium; cAMP

Several studies have demonstrated the potential of flavonoids for the prevention and/or intervention of various allergic diseases. One such naturally occurring flavonoid is silibinin (Fig. 1), which is the major biologically active constituent in silymarin that is a defined mixture of polyphenolic flavonoids isolated from the milk thistle (Silybum marianum) extract. Silibinin has high human acceptance being used clinically and consumed as dietary supplement around the world for its strong anti-hepatotoxic efficacy. ${ }^{1,2)}$ A wide range of studies have shown that silibinin exhibits cancer-preventive and anti-carcinogenic effects. ${ }^{3,4)}$ Moreover, silibinin possesses a variety of additional biological effects, such as antioxidative $^{5)}$ and anti-inflammatory effects. ${ }^{\text {) }}$

Immediate-type hypersensitivity (anaphylaxis) is an acute and life-threatening allergic reaction that occurs massively and systemically. Mast cells play a key role in allergic diseases through the release of a number of mediators and cytokines. ${ }^{7)}$ The secretory response of mast cells can be induced by aggregation of their cell surface-specific receptors (FceRI) for immunoglobulin (Ig) E by the corresponding antigen. ${ }^{8)}$ Activated mast cells can produce histamine, as well as a wide variety of other inflammatory mediators such as leukotrienes, prostaglandins, proteases and several pro-inflammatory and chemotactic cytokines such as tumor necrosis factor (TNF)- $\alpha$ and interleukins (IL)-6, IL-4, IL-13, IL8. ${ }^{9)}$ Among these substances, histamine remains the bestcharacterized and most potent vasoactive mediator impli-

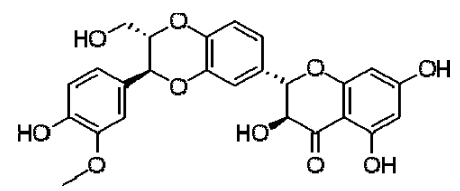

Fig. 1. Chemical Structure of Silibinin

Silibinin is a bioactive flavanone and a major component of milk thistle extract isolated from Silybum marianum. cated in the acute phase of immediate hypersensitivity. ${ }^{10)}$ Mast cell degranulation can also be elicited by non-immunologic stimulators such as neuropeptides, basic compounds, complement components and certain drugs. ${ }^{11)}$ Compound $48 / 80$, a mixed polymer of phenethylamine cross-linked by formaldehyde, is the potent secretagogue for mast cells. ${ }^{12)} \mathrm{It}$ vigorously activates cellular exocytosis, inducing a rapid release of inflammatory mediators including such as histamine. Thus, compound $48 / 80$ has been used as a direct and convenient reagent to study the mechanism of allergy and anaphylaxis. ${ }^{13)}$ Additionally, murine mast cell is a good experimental model for the study of the mechanism of stimulus-secretion coupling.

In the earlier work, Lecomte and Damas reported mast cell protection against dextran induced by silybin (silibinin). ${ }^{14)}$ Moreover, it was shown that silybin inhibited anaphylactic shock in rats sensitized by ovalbumin and concluded that silybin seemed to be a stabilizer of mast cell membrane, thus preventing histamine release. ${ }^{15)}$ Furthermore, Miadonna et $a l$. demonstrated that silybin, one of the pure active agents in silymarin, might have anti-allergic activity via inhibition of histamine release from human basophils. ${ }^{16)}$ Recently, silymarin has been suggested to have a protective effect in the early-phase of allergic asthma. ${ }^{17)}$ Nevertheless, to our knowledge, a detail relationship between silibinin and mast cellmediated anaphylaxis-like reactions has not yet been fully understood.

The objective of the present study is to investigate whether silibinin can inhibit mast cell-mediated anaphylaxis-like reactions. Our results will give an insight into the prevention or treatment of mast cell-dependent allergic diseases.

\section{MATERIALS AND METHODS}

Materials Silibinin, compound 48/80, azelastine, antidinitrophenyl (DNP) IgE, DNP-human serum albumin 
(HSA), anti-actin antibody and $N$-(2-hydroxyethyl)piperazine$N^{\prime}$-2-ethanesulfonic acid (HEPES) were purchased from Sigma Chemical Co. (St. Louis, MO, U.S.A.). Percoll solution was purchased from Pharmacia (Uppsala, Sweden). Silibinin was dissolved in dimethyl sulfoxide (DMSO) and freshly diluted in phosphate-buffered saline (PBS) for all in vitro experiments. The anti-DNP IgE, DNP-HSA and compound 48/80 were also diluted in PBS.

Experimental Animals Male ICR mice and SpragueDawley rats were purchased from Damool Science (Daejeon, Korea). Animals were housed $3-5$ per cages in laminar airflow cabinet maintained at $22 \pm 1{ }^{\circ} \mathrm{C}$ and relative humidity of $55 \pm 10 \%$ throughout the study. All experiments were performed in compliance with the guidelines approved by Institutional Animal Care and Use Committee of Yanbian University School of Medical Sciences.

Anti-DNP IgE-Mediated Passive Systemic Anaphylaxis (PSA) in Mice Mice ( $n=10$ /group) were intravenously injected with $3 \mu \mathrm{g}$ anti-DNP IgE. Twenty-four hours later, mice were challenged with intravenously administration of $500 \mu \mathrm{g}$ of antigen (DNP-HSA) or PBS. After $1.5 \mathrm{~min}$, mice were sacrificed by cervical dislocation and blood was immediately collected by cardiac puncture. Serum was isolated from blood samples and tested for serum histamine concentration by the radioenzymatic method. ${ }^{18)}$ Silibinin [10, 50, $100 \mathrm{mg}$ / $\mathrm{kg}$ body weight (BW)] was suspended in PBS and administered orally at 24,12 and $1 \mathrm{~h}$ before the antigen challenge.

Compound 48/80-Induced or Anti-DNP IgE-Mediated Passive Cutaneous Anaphylaxis (PCA)-Like Reaction After the intradermal injection of $0.5 \mu \mathrm{g} / 20 \mu \mathrm{l}$ compound $48 / 80$ in the dorsal skin of each mouse, $2 \%$ Evans blue solution was intravenously injected into the lateral tail vein of each mouse. The next steps were conducted following the procedures outlined in the next paragraph. Anti-DNP IgEmediated PCA was examined as reported previously. ${ }^{19)}$ Mice were sensitized in the right dorsal skin by the intradermal injection of $200 \mathrm{ng}$ anti-DNP IgE in $20 \mu \mathrm{l} \mathrm{PBS}$ and were given a sham PBS injection in the left dorsal skin. Twenty-four hours later, the mice received into the lateral tail vein an injection of $200 \mu \mathrm{l}$ of PBS containing $100 \mu \mathrm{g}$ DNP-HSA with $2 \%$ Evans blue. Silibinin was administered orally at 24,12 and $1 \mathrm{~h}$ before the injection of compound $48 / 80$ or antigen challenge. As a control, an anti-histamine and mast cellstabilizing agent, azelastine, was orally given at 24, 12 and $1 \mathrm{~h}$ prior to the injection of compound $48 / 80$ or challenge with antigen.

Thirty minutes after the $2 \%$ Evans blue injection or challenge, the mice were killed by terminal anaesthesia, tissue sections around the intradermal injection site excised and weighed, followed by extraction of extravasated Evans blue dye by incubation of biopsies in $1 \mathrm{ml}$ formamide at $55^{\circ} \mathrm{C}$ for $24 \mathrm{~h}$ and measurement of absorbance at $620 \mathrm{~nm}$ using a spectrophotometer (Spectra MAX PLUS, Molecular Devices, CA, U.S.A.). Tissue Evans blue concentrations were quantified by interpolation on a standard curve of dye concentrations in the range of 0.01 to $30 \mu \mathrm{g} / \mathrm{ml}$.

Preparation of Mast Cell Suspension Rat peritoneal mast cells (RPMC) were isolated as described previously. ${ }^{20)}$ In brief, rats were anesthetized with ether and injected with $10 \mathrm{ml}$ of calcium-free HEPES-Tyrode buffer into the peritoneal cavity, and the abdomen was gently massaged for about $90 \mathrm{~s}$. The peritoneal cavity was opened, and the fluid was aspirated using a Pasteur pipette, and RPMC were purified by using a Percoll density gradient as described in detail elsewhere. ${ }^{21)}$ RPMC preparations were at least $95 \%$ pure as assessed by toluidine blue staining and at least $98 \%$ of these cells were viable as judged by trypan blue exclusion. Purified mast cells $\left(1 \times 10^{6}\right.$ cells $\left./ \mathrm{ml}\right)$ were resuspended in HEPESTyrode buffer.

Mast Cell Viability Assay To test the viability of cells, the 3-(4,5-dimethylthiazol-2-yl)-2,5-diphenyltetrazolium bromide (MTT) colorimetric assay was performed as described previously. ${ }^{22}$ Briefly, RPMC $\left(2 \times 10^{5}\right.$ cells/well $)$ were incubated with various concentrations $(25,50,100 \mu \mathrm{M})$ of silibinin at $37^{\circ} \mathrm{C}$ for $2 \mathrm{~h}$. After addition of MTT $(100 \mu \mathrm{g}$ in 100 $\mu \mathrm{l}$ PBS), cells were incubated at $37^{\circ} \mathrm{C}$ for $1 \mathrm{~h}$. The crystallized MTT was dissolved, and the absorbance was measured at $570 \mathrm{~nm}$ with a spectrophotometer.

Assay of Histamine Release Mast cell suspensions $\left(2 \times 10^{5}\right.$ cells in $\left.200 \mu \mathrm{l}\right)$ were preincubated with silibinin $(25$, $50,100 \mu \mathrm{M})$ or the vehicle only $(0.3 \%$ DMSO, used as a control) at $37^{\circ} \mathrm{C}$ for $15 \mathrm{~min}$ and then incubated with compound $48 / 80(0.25 \mu \mathrm{g} / \mathrm{ml})$ for $20 \mathrm{~min}$. In addition, RPMC were sensitized with $10 \mu \mathrm{g} / \mathrm{ml}$ anti-DNP IgE for $18 \mathrm{~h}$ and preincubated with silibinin or the vehicle at $37^{\circ} \mathrm{C}$ for $15 \mathrm{~min}$ prior to the challenge with DNP-HSA $(100 \mathrm{ng} / \mathrm{ml})$. Furthermore, PBS- or IgE-pretreated RPMC were incubated with silibinin $(100 \mu \mathrm{M})$ for indicated time at $37^{\circ} \mathrm{C}$ prior to the stimulation with compound $48 / 80$ or DNP-HSA, respectively. Following centrifugation at $150 \times \boldsymbol{g}$ for $10 \mathrm{~min}$, the amount of histamine in the supernatant was determined by the radioenzymatic method. ${ }^{18)}$ The inhibition percentage of histamine release was calculated using the following formula:

inhibition $(\%)=\{1-(T-B) /(C-N)\} \times 100$

Control $(C)$ : anti-DNP IgE or compound 48/80 (+), silibinin $(-)$; Normal $(N)$ : anti-DNP IgE or compound $48 / 80$ $(-)$, silibinin $(-)$; Test $(T)$ : anti-DNP IgE or compound $48 /$ $80(+)$, silibinin $(+)$; Blank $(B)$ : anti-DNP IgE or compound 48/80 (-), silibinin (+).

Assay of TNF- $\alpha$ and IL-6 Secretion RPMC were sensitized with $10 \mu \mathrm{g} / \mathrm{ml}$ anti-DNP IgE for $18 \mathrm{~h}$ and then stimulated with $100 \mathrm{ng} / \mathrm{ml} \mathrm{DNP-HSA}$ for $30 \mathrm{~min}$ with or without silibinin. TNF- $\alpha$ and IL-6 concentrations in the supernatant were determined by using commercial enzyme-linked immunosorbent assay (ELISA) kits, according to the manufacturer's instructions (Invitrogen-Biosource Cytokine \& Signaling, Camarillo, CA, U.S.A.). The inhibition rate of the production of TNF- $\alpha$ and IL- 6 by silibinin was calculated using the following equation:

\section{inhibition $(\%)=\{1-(T-B) /(C-N)\} \times 100$}

Control $(C)$ : anti-DNP IgE $(+)$, silibinin $(-)$; Normal $(N)$ : anti-DNP $\operatorname{IgE}(-)$, silibinin $(-)$; Test $(T)$ : anti-DNP $\operatorname{IgE}(+)$, silibinin (+); Blank $(B)$ : anti-DNP IgE $(-)$, silibinin $(-)$.

Measurement of ${ }^{45} \mathrm{Ca}$ Uptake The calcium uptake of mast cells was measured according to the method described by Choi et al. ${ }^{23)}$ Purified mast cells were resuspended in HEPES-Tyrode buffer containing ${ }^{45} \mathrm{Ca}(1.5 \mathrm{mCi} / \mathrm{ml} ; 1 \mathrm{Ci}=$ $3.7 \times 10^{10} \mathrm{~Bq}$; Perkin-Elmer Life Sciences, MA, U.S.A.) and incubated at $4{ }^{\circ} \mathrm{C}$ for $10 \mathrm{~min}$. Mast cell suspensions were sensitized with $10 \mu \mathrm{g} / \mathrm{ml}$ anti-DNP IgE for $18 \mathrm{~h}$ and preincu- 
bated with silibinin at $37^{\circ} \mathrm{C}$ for $15 \mathrm{~min}$ prior to the challenge with DNP-HSA $(100 \mathrm{ng} / \mathrm{ml})$. The reaction was stopped by the addition of $1 \mathrm{~mm}$ lanthanum chloride. The samples were centrifuged 3 times at $150 \times \boldsymbol{g}$ for $10 \mathrm{~min}$ at $4{ }^{\circ} \mathrm{C}$, and then the mast cells were lysed with $10 \%$ Triton X-100 and vigorous shaking. Radioactivity of the solution was measured in a scintillation ß-counter (Liquid Scintillation Analyzer, A Canberra Company, Australia). The inhibition percentage of ${ }^{45} \mathrm{Ca}$ uptake by silibinin was calculated using the following formula:

\section{inhibition $(\%)=\{1-(T-B) /(C-N)\} \times 100$}

Control $(C)$ : anti-DNP IgE $(+)$, silibinin $(-)$; Normal $(N)$ : anti-DNP $\operatorname{IgE}(-)$, silibinin $(-)$; Test $(T)$ : anti-DNP $\operatorname{IgE}(+)$, silibinin $(+)$; Blank $(B)$ : anti-DNP IgE $(-)$, silibinin $(+)$.

Cytosolic and Nuclear Protein Extractions for Analysis of Nuclear Factor-Kappa B (NF- $\mathbf{k}$ ) RPMC were sensitized with $10 \mu \mathrm{g} / \mathrm{ml}$ anti-DNP $\operatorname{IgE}$ for $18 \mathrm{~h}$ and preincubated with silibinin or the vehicle at $37^{\circ} \mathrm{C}$ for $15 \mathrm{~min}$ prior to the challenge with DNP-HSA $(100 \mathrm{ng} / \mathrm{ml})$. The cells were harvested and washed twice with ice-cold PBS. The washed cell pellets were resuspended in 2 volumes of buffer A $(50 \mathrm{~mm}$ Tris- $\mathrm{HCl}, \mathrm{pH}$ 7.5, $1 \mathrm{~mm}$ ethylenediaminetetraacetic acid (EDTA), $10 \%$ glycerol, $0.5 \mathrm{~mm}$ DTT, $5 \mathrm{~mm} \mathrm{MgCl}_{2}, 1 \mathrm{~mm}$ phenyl methylsulfonyl fluoride (PMSF) and protease inhibitor cocktails). This suspension was centrifuged at $1000 \times$ $\boldsymbol{g}$ for $15 \mathrm{~min}$ at $4{ }^{\circ} \mathrm{C}$. The supernatant fraction was incubated on ice for $10 \mathrm{~min}$ and centrifuged at $100000 \times \boldsymbol{g}$ for $1 \mathrm{~h}$ at $4{ }^{\circ} \mathrm{C}$ to obtain cytosolic protein extracts. The pellets were washed twice in buffer $\mathrm{A}$ and resuspended in buffer $\mathrm{B}(1.3 \mathrm{M}$ sucrose, $1.0 \mathrm{~mm} \mathrm{MgCl}_{2}$ and $10 \mathrm{~mm}$ potassium phosphate buffer, pH 6.8) and pelleted at $1000 \times \boldsymbol{g}$ for $15 \mathrm{~min}$. The pellets were suspended in buffer B with a final sucrose concentration of $2.2 \mathrm{M}$ and centrifuged at $100000 \times \mathbf{g}$ for $1 \mathrm{~h}$. The resulting nuclear pellets were washed once with a solution containing $0.25 \mathrm{M}$ sucrose, $0.5 \mathrm{~mm} \mathrm{MgCl}_{2}$ and $20 \mathrm{~mm}$ Tris- $\mathrm{HCl}$, $\mathrm{pH} 7.2$, and centrifuged at $1000 \times \boldsymbol{g}$ for $10 \mathrm{~min}$. The pellets were solubilized with a solution containing $50 \mathrm{~mm}$ Tris- $\mathrm{HCl}$ (pH 7.2), $0.3 \mathrm{~m}$ sucrose, $150 \mathrm{~mm} \mathrm{NaCl}, 2$ mм EDTA, 20\% glycerol, $2 \%$ Triton X-100, $2 \mathrm{~mm}$ PMSF and protease inhibitor cocktails. The mixture was kept on ice for $1 \mathrm{~h}$ with gentle stirring and centrifuged at $12000 \times \boldsymbol{g}$ for $30 \mathrm{~min}$. The resulting supernatant was used as soluble nuclear proteins.

For Western blotting analysis, samples $(30 \mu \mathrm{g}$ of protein per lane) were loaded on a 10\% SDS-PAGE gel. After electrophoresis at $120 \mathrm{~V}$ for $90 \mathrm{~min}$, separated proteins were transferred to polyvinylidene difluoride membranes (Amersham Pharmacia Biotech, Piscataway, NJ, U.S.A.) by the wet transfer method (250 mA, $90 \mathrm{~min}$ ). Nonspecific sites were blocked with $5 \%$ nonfat dry milk in TBST buffer $(25 \mathrm{~mm}$ Tris, $\mathrm{pH}$ $7.5,150 \mathrm{~mm} \mathrm{NaCl}, 0.1 \%$ Tween 20 ) for $1 \mathrm{~h}$, and the blots were incubated with antibody against NF- $\kappa \mathrm{B}$ p65 (Upstate Biotech, Lake Placid, NY, U.S.A.) overnight at $4{ }^{\circ} \mathrm{C}$. Antirabbit horseradish peroxidase conjugated $\mathrm{IgG}$ was used to detect binding of antibodies. The binding of the specific antibodies was visualized by exposing to photographic film after treating with enhanced chemiluminescence system reagents (Amersham Pharmacia Biotech).

Measurement of cAMP Level The cyclic adenosine$3^{\prime}, 5^{\prime}$ monophosphate (cAMP) level was measured by the method described by Holmegaard. ${ }^{24)}$ In brief, mast cell sus- pensions were added to an equivalent volume $(200 \mu \mathrm{l})$ of prewarmed buffer containing silibinin $(100 \mu \mathrm{M})$ in an Eppendorf tube. The reaction was allowed to proceed for discrete time intervals, terminated by centrifugation, and then each sample was added to $250 \mu \mathrm{l}$ of $50 \mathrm{~mm}$ sodium acetate buffer ( $\mathrm{pH}$ 6.2) under vigorous vortexing, followed by snap frozen in liquid nitrogen. The frozen samples were thawed and vortexed, and then the debris were sedimented by a centrifugation $1200 \times \boldsymbol{g}$ at $4{ }^{\circ} \mathrm{C}$ for $10 \mathrm{~min}$. The cAMP level in the supernatant was determined by radioimmunoassay using a Rianen assay system (Perkin-Elmer Life Sciences, MA, U.S.A.).

Statistical Analysis The results obtained were expressed as mean \pm S.E.M. for the number of experiments. Statistical evaluation of the results was performed using one-way ANOVA, followed by Duncan's multiple range tests. Results with $p<0.05$ were considered statistically significant.

\section{RESULTS}

Effect of Silibinin on Anti-DNP IgE-Mediated PSA IgE-mediated PSA is dependent upon passive transfer of anti-DNP IgE followed by intravenous administration of the antigen. Oral infusion of silibinin dose-dependently inhibited anti-DNP IgE-mediated PSA in mice (Table 1).

Effect of Silibinin on Compound 48/80-Induced or Anti-DNP IgE-Mediated PCA-Like Reaction It has been previously demonstrated that the intradermal injection of compound 48/80 into the dorsal skin of mice provokes the increase of mast cell-dependent vascular permeability documented by Evans blue extravasation. ${ }^{25)}$ As shown in Table 2, oral administration of silibinin dose-dependently reduced vascular permeability changes induced by compound $48 / 80$. Local extravasation was also induced by a local injection of anti-DNP IgE followed by an intravenous antigenic challenge. Pretreatment of silibinin caused a dose-dependent decrease in anti-DNP IgE-mediated PCA (Table 3). Likewise, azelastine exhibited significant inhibition of PCA-like reactions triggered by compound $48 / 80$ or antigen at the dose of $10 \mathrm{mg} / \mathrm{kg}$ body weight (BW).

\section{Effect of Silibinin on Mast Cell Viability MTT conver-}

Table 1. Inhibitory Effect of Silibinin on Anti-DNP IgE-Mediated Passive Systemic Anaphylaxis in Mice

\begin{tabular}{lrccc}
\hline \hline $\begin{array}{c}\text { Treatment } \\
(\mathrm{mg} / \mathrm{kg} \mathrm{BW})\end{array}$ & Anti-DNP IgE & $\begin{array}{c}\text { Histamine } \\
\text { concentration } \\
(\mu \mathrm{g} / \mathrm{ml})\end{array}$ & Inhibition $^{a)}(\%)$ \\
\hline None (PBS) & & - & $0.12 \pm 0.01$ & - \\
Silibinin & 10 & - & $0.13 \pm 0.02$ & - \\
& 50 & - & $0.12 \pm 0.01$ & - \\
& 100 & - & $0.11 \pm 0.01$ & - \\
Azelastine & 10 & - & $0.12 \pm 0.01$ & - \\
None (PBS) & & + & $1.30 \pm 0.14$ & - \\
Silibinin & 10 & + & $1.02 \pm 0.19$ & 24.58 \\
& 50 & + & $0.83 \pm 0.07 *$ & 39.83 \\
& 100 & + & $0.67 \pm 0.03^{*}$ & 52.54 \\
Azelastine & 10 & + & $0.45 \pm 0.04^{*}$ & 72.03
\end{tabular}

Silibinin was administered orally at 24,12 and $1 \mathrm{~h}$ prior to the challenge with antigen (DNP-HSA). Each serum histamine concentration represents the mean \pm S.E.M. of five independent experiments. a) Inhibition $(\%)=\{1-(T-B) /(C-N)\} \times 100$. Control $(C)$ : anti-DNP IgE $(+)$, silibinin $(-)$; Normal $(N)$ : anti-DNP $\operatorname{IgE}(-)$, silibinin $(-)$; Test $(T)$ : anti-DNP IgE $(+)$, silibinin $(+)$; Blank $(B)$ : anti-DNP IgE $(-)$, silibinin $(+)$. $* p<0.05$, significantly different from the control value. Azelastine $(10 \mathrm{mg} / \mathrm{kg})$ was used as a typical anti-allergic control drug. 
Table 2. Inhibitory Effect of Silibinin on Compound 48/80-Induced Passive Cutaneous Anaphylaxis-Like Reaction in Mice

\begin{tabular}{|c|c|c|c|c|}
\hline \multicolumn{2}{|c|}{$\begin{array}{l}\text { Treatment } \\
(\mathrm{mg} / \mathrm{kg} \mathrm{BW})\end{array}$} & $\begin{array}{c}\text { Compound } 48 / 80 \\
(0.5 \mu \mathrm{g} / \text { site })\end{array}$ & $\begin{array}{c}\text { Amount of } \\
\text { Evans blue } \\
(\mu \mathrm{g} / \mathrm{g})\end{array}$ & $\begin{array}{c}\text { Inhibition }^{a)} \\
(\%)\end{array}$ \\
\hline \multicolumn{2}{|l|}{ None (PBS) } & - & $43.19 \pm 2.27$ & - \\
\hline \multirow[t]{3}{*}{ Silibinin } & 10 & - & $41.22 \pm 2.43$ & - \\
\hline & 50 & - & $45.06 \pm 3.10$ & - \\
\hline & 100 & - & $42.96 \pm 2.85$ & - \\
\hline Azelastine & 10 & - & $41.38 \pm 1.74$ & - \\
\hline \multicolumn{2}{|l|}{ None (PBS) } & + & $313.51 \pm 20.28$ & - \\
\hline \multirow[t]{3}{*}{ Silibinin } & 10 & + & $247.83 \pm 19.64$ & 23.68 \\
\hline & 50 & + & $189.37 \pm 12.81^{*}$ & 46.62 \\
\hline & 100 & + & $124.92 \pm 7.59 *$ & 69.67 \\
\hline Azelastine & 10 & + & $106.75 \pm 9.38^{*}$ & 75.82 \\
\hline
\end{tabular}

Silibinin was administered orally at 24,12 and $1 \mathrm{~h}$ before the injection of compound $48 / 80$. Twenty microliters of compound $48 / 80(0.5 \mu \mathrm{g} / \mathrm{site})$ were intradermally injected to the backs of mice. Each amount of Evans blue represents the mean \pm S.E.M. of five independent experiments. a) Inhibition $(\%)=\{1-(T-B) /(C-N)\} \times 100$. Control $(C)$ : compound 48/80 (+), silibinin $(-)$; Normal $(N)$ : compound 48/80 $(-)$, silibinin $(-)$; Test $(T)$ : compound 48/80 (+), silibinin $(+)$; Blank $(B)$ : compound 48/80 $(-)$, silibinin $(+) . * p<0.05$, significantly different from the control value. Azelastine $(10 \mathrm{mg} / \mathrm{kg})$ was used as a typical anti-allergic control drug.

Table 3. Inhibitory Effect of Silibinin on Anti-DNP IgE-Mediated Passive Cutaneous Anaphylaxis in Mice

\begin{tabular}{|c|c|c|c|c|}
\hline \multicolumn{2}{|c|}{$\begin{array}{c}\text { Treatment } \\
(\mathrm{mg} / \mathrm{kg} \mathrm{BW})\end{array}$} & Anti-DNP IgE & $\begin{array}{c}\text { Amount of } \\
\text { Evans blue } \\
(\mu \mathrm{g} / \mathrm{g})\end{array}$ & $\begin{array}{c}\text { Inhibition }^{a)} \\
(\%)\end{array}$ \\
\hline \multicolumn{2}{|l|}{ None (PBS) } & - & $55.72 \pm 4.31$ & - \\
\hline \multirow[t]{3}{*}{ Silibinin } & 10 & - & $56.38 \pm 5.26$ & - \\
\hline & 50 & - & $53.26 \pm 3.67$ & - \\
\hline & 100 & - & $52.59 \pm 3.42$ & - \\
\hline Azelastine & 10 & - & $54.13 \pm 6.80$ & - \\
\hline \multicolumn{2}{|l|}{ None (PBS) } & + & $270.26 \pm 16.22$ & - \\
\hline \multirow[t]{3}{*}{ Silibinin } & 10 & + & $176.18 \pm 13.89 *$ & 44.16 \\
\hline & 50 & + & $147.45 \pm 11.57^{*}$ & 56.10 \\
\hline & 100 & + & $134.70 \pm 10.14 *$ & 61.73 \\
\hline Azelastine & 10 & + & $96.53 \pm 7.90 *$ & 80.24 \\
\hline
\end{tabular}

Silibinin was administered orally at 24,12 and $1 \mathrm{~h}$ prior to the challenge with antigen (DNP-HSA). Each amount of Evans blue represents the mean \pm S.E.M. of five independent experiments. a) Inhibition $(\%)=\{1-(T-B) /(C-N)\} \times 100$. Control $(C)$ : antiDNP IgE $(+)$, silibinin $(-)$; Normal $(N)$ : anti-DNP $\operatorname{IgE}(-)$, silibinin $(-)$; Test $(T)$ : anti-DNP IgE $(+)$, silibinin $(+)$; Blank $(B)$ : anti-DNP IgE $(-)$, silibinin $(+) * p<0.05$, significantly different from the control value. Azelastine $(10 \mathrm{mg} / \mathrm{kg})$ was used as a typical anti-allergic control drug.

sion assay was used to determine the viability of RPMC exposed to silibinin. The viable cells were almost $100 \%$ after exposure to $100 \mu \mathrm{M}$ silibinin for $2 \mathrm{~h}$ (data not shown). Thus, silibinin had no cytotoxicity on RPMC.

Effect of Silibinin on Histamine Release from RPMC The effect of silibinin on compound 48/80-induced histamine release from RPMC was shown (Fig. 2A). The histamine release from compound 48/80-treated RPMC was reduced in a dose-dependent manner of silibinin (82 and 91\% inhibition at 50 and $100 \mu \mathrm{M}$, respectively). Moreover, the inhibitory effect of silibinin on IgE-mediated histamine release from RPMC was documented in Fig. 2B. Silibinin dose-dependently inhibited IgE-mediated histamine release from RPMC (79 and 95\% inhibition at 50 and $100 \mu \mathrm{M}$, respectively). Azelastine also showed a significant inhibitory potency on compound 48/80 or IgE-induced histamine release at the dose of $100 \mu \mathrm{M}$ (94 and 98\% inhibition, respectively). These results
A
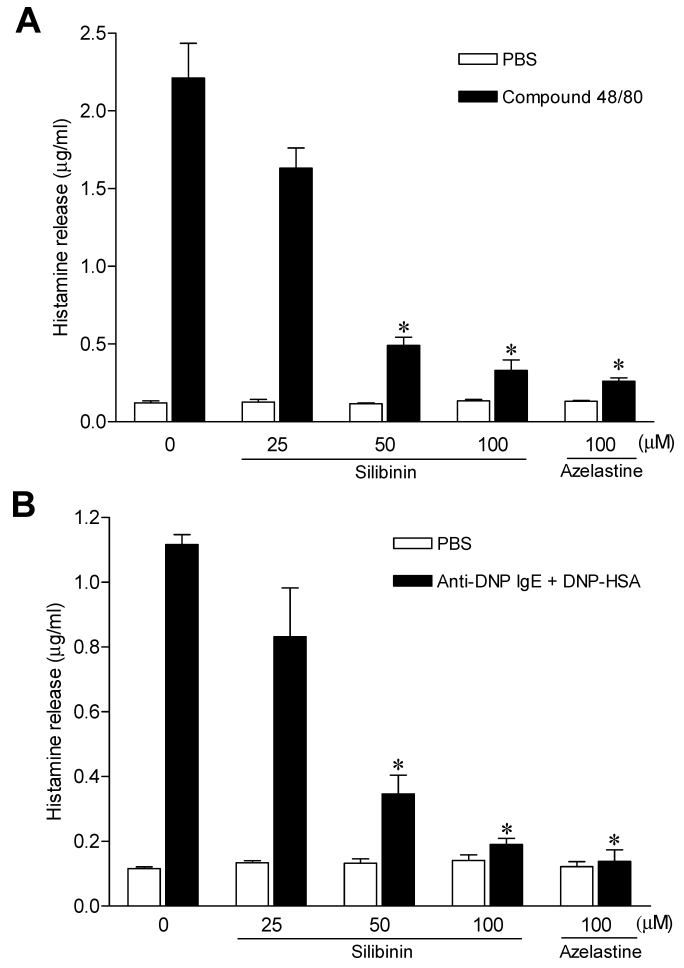

Fig. 2. Inhibitory Effect of Silibinin on Compound 48/80- or Anti-DNP IgE-Induced Histamine Release from Rat Peritoneal Mast Cells (RPMC)

RPMC were preincubated with silibinin at $37^{\circ} \mathrm{C}$ for $15 \mathrm{~min}$ prior to the incubation with compound $48 / 80$ (A) or DNP-HSA (B). Each data value represents the mean \pm S.E.M. of five independent experiments. $* p<0.05$, significantly different from the control value.

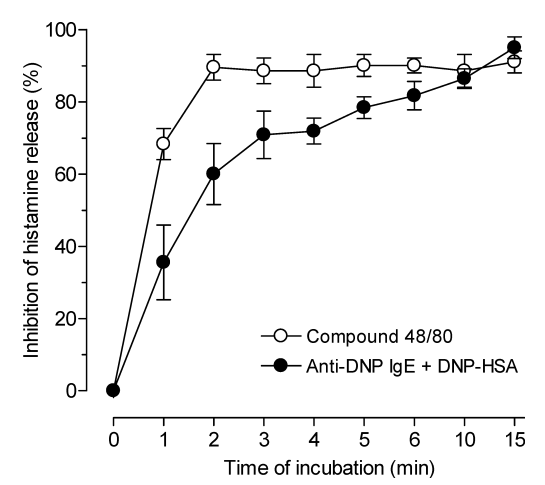

Fig. 3. Time-Course Effect of Silibinin on Histamine Release from Rat Peritoneal Mast Cells (RPMC)

RPMC were preincubated with silibinin $(100 \mu \mathrm{M})$ for indicated time at $37^{\circ} \mathrm{C}$ prior to the incubation with compound $48 / 80(\bigcirc)$ or DNP-HSA $(\bullet)$. Each data value represents the mean \pm S.E.M. of five independent experiments.

indicate that silibinin inhibits the compound 48/80- or IgEinduced anaphylaxis-like reaction by blocking histamine release from RPMC.

Time-Course Effect of Silibinin on Histamine Release from RPMC As shown in Fig. 3, time-course study revealed that the inhibition of compound 48/80- and IgE-induced histamine release was observed at $1 \mathrm{~min}$ after RPMC were preincubated with silibinin (68 and $35 \%$ inhibition, respectively). The peak inhibition of histamine release occurred at 2 and $15 \mathrm{~min}$ for compound 48/80- and IgE-treated groups, respectively, following preincubation with silibinin. In addition, silibinin showed no loss of inhibitory effect on histamine release when RPMC were preincubated with the 
A

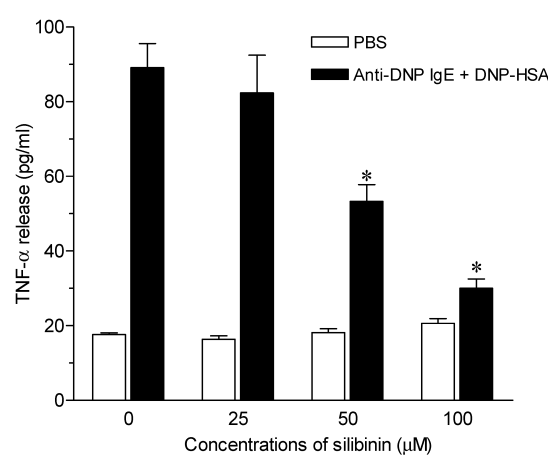

B

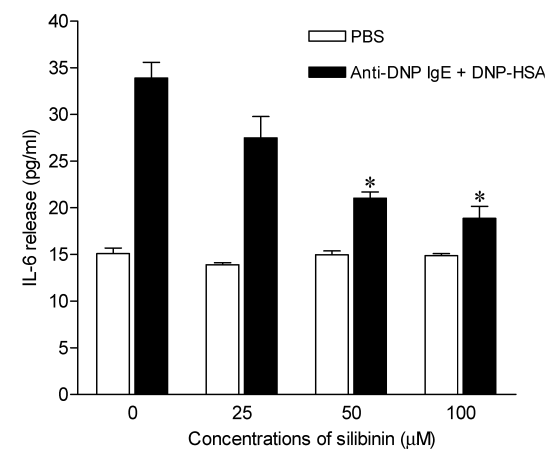

Fig. 4. Inhibitory Effect of Silibinin on Anti-DNP IgE-Induced Cytokine Production (A, TNF- $\alpha$; B, IL-6) in Rat Peritoneal Mast Cells (RPMC)

RPMC were sensitized with anti-DNP IgE and preincubated at $37^{\circ} \mathrm{C}$ for $15 \mathrm{~min}$ in the absence or presence of silibinin before the challenge with DNP-HSA. The level of cytokine in the supernatant was measured by using ELISA. Each data value represents the mean \pm S.E.M. of five independent experiments. $* p<0.05$, significantly different from the control value.

\section{drug for $15 \mathrm{~min}$.}

Effect of Silibinin on Anti-DNP IgE-Mediated TNF- $\alpha$ and IL-6 Secretion Activation of mast cells also stimulates cytokine release. Thus, we next determined whether silibinin could modify the release of cytokines. RPMC stimulated with anti-DNP IgE released significantly more TNF- $\alpha$ and IL-6 (89.15 \pm 4.54 and $33.89 \pm 1.71 \mathrm{pg} / \mathrm{ml}$, respectively) when compared to normal group (RPMC treated with equal amount of PBS only; $17.62 \pm 0.45$ and $15.10 \pm 0.61 \mathrm{pg} / \mathrm{ml}$, respectively). Preincubation of RPMC with silibinin significantly prevented anti-DNP IgE-mediated TNF- $\alpha$ release (Fig. $4 \mathrm{~A})$ at 50 and $100 \mu \mathrm{M}$ (51 and $86 \%$ inhibition, respectively). Additionally, silibinin $(50,100 \mu \mathrm{M})$ significantly reduced IL6 secretion in a dose-dependent manner by $68 \%$ and $79 \%$, respectively (Fig. 4B).

Effect of Silibinin on Calcium Uptake into RPMC Calcium plays an important role in the stimulus-secretion coupling of mast cells. Especially calcium uptake into mast cells has been recognized as one of the chief elements leading to a secretory response. ${ }^{26)}$ Therefore, we measured the calcium uptake. Treatment with silibinin alone showed no change in calcium uptake. However, calcium uptake was substantially increased by the stimulation of RPMC with antiDNP IgE (data not shown). The antigen-elicited calcium uptake was inhibited in a concentration-dependent manner of silibinin (Fig. 5). At the concentration of $100 \mu \mathrm{M}$ of silibinin, the antigen-mediated calcium uptake was near-completely blocked. Azelastine (reference drug) also significantly inhibited antigen-induced calcium uptake at 25,50 and $100 \mu \mathrm{M}$. These findings suggest that silibinin may inhibit mediator re-

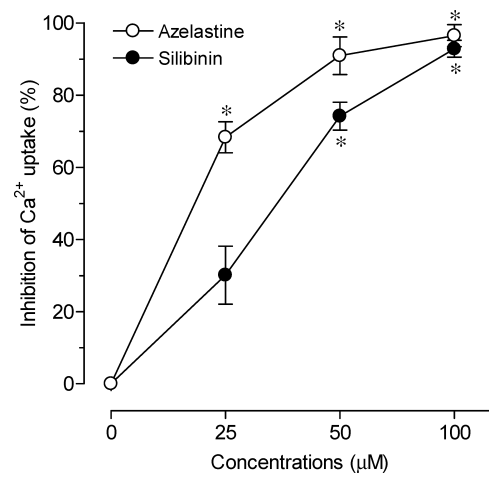

Fig. 5. Inhibitory Effect of Silibinin on Anti-DNP IgE-Mediated Calcium Uptake in Rat Peritoneal Mast Cells (RPMC)

RPMC were sensitized with anti-DNP IgE and preincubated at $37^{\circ} \mathrm{C}$ for $15 \mathrm{~min}$ in the absence or presence of silibinin before the challenge with DNP-HSA. Each data value represents the mean \pm S.E.M. of five independent experiments. $* p<0.05$, significantly different from the control value.

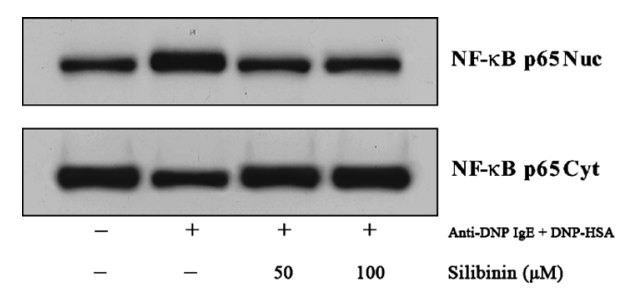

Fig. 6. Effect of Silibinin on NF- $\kappa$ B Expression in Nuclear and Cytosolic Protein Extracts from Anti-DNP IgE-Stimulated Rat Peritoneal Mast Cells (RPMC)

NF- $\kappa$ B p65 expression in nuclear (Nuc) and cytosolic (Cyt) protein extracts from RPMC was shown. A representative result was presented among at least five separate experiments with similar results.

lease through blocking calcium uptake into RPMC.

Effect of Silibinin on NF- $\boldsymbol{K B}$ Activity Western blot analysis revealed that levels of NF- $\kappa \mathrm{B}$ p 65 protein in nuclear protein extracts from anti-DNP IgE-stimulated RPMC were increased compared with the levels in the normal group (Fig. 6). The increased NF- $\kappa \mathrm{B}$ p65 levels upon antigenic stimulation were decreased by the pretreatment of silibinin. In contrast, levels of NF- $\kappa \mathrm{B}$ p65 protein in cytosolic protein extracts from anti-DNP IgE-stimulated RPMC were decreased compared with the levels in the normal group (Fig. 6). The decreased NF- $\kappa$ B p 65 levels in cytosol preparations were increased by the pretreatment of silibinin. These data indicate that silibinin inhibits NF- $\kappa \mathrm{B}$ activity by preventing translocation of this transcription factor into the nucleus.

Effect of Silibinin on cAMP Level of RPMC Preliminary reports have shown that the cAMP pathway participated in the modulation of mast cell activation. Increased cAMP is known to precede the prevention of mediator release from mast cells activated by compound $48 / 80$ or IgE. ${ }^{27)}$ To investigate the mechanism of silibinin on the reduction of mediator release from RPMC stimulated by compound $48 / 80$ or IgE, we assessed the intracellular cAMP level. The level of cAMP was not changed in unstimulated RPMC. When RPMC were incubated with silibinin at $100 \mu \mathrm{M}$, the cAMP level increased at $1-5 \mathrm{~min}$ and decreased to basal level from $6 \mathrm{~min}$ (Fig. 7). These results propose that silibinin may inhibit mediator release by increasing the cAMP level in RPMC. 


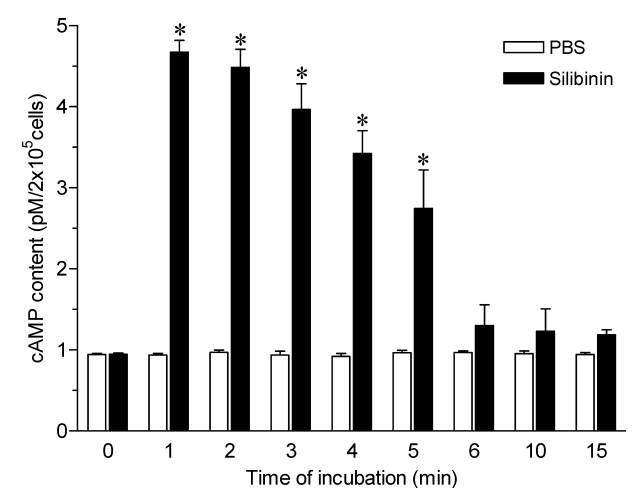

Fig. 7. Effect of Silibinin on the cAMP Levels in Rat Peritoneal Mast Cells (RPMC)

RPMC were incubated with silibinin $(100 \mu \mathrm{M})$ for indicated time at $37^{\circ} \mathrm{C}$. Each data value represents the mean \pm S.E.M. of five independent experiments. $* p<0.05$, significantly different from the samples treated with PBS alone.

\section{DISCUSSION}

The in vivo models of anaphylaxis-like reaction were designed to assess the contribution of silibinin in mast cell-dependent anaphylactoid reactions. Silibinin-administered mice are protected from compound 48/80-induced PCA-like reaction in a dose-dependent manner. To further investigate the mechanism by which silibinin inhibits the anaphylaxis-like reaction, an in vitro study has been performed. The inhibitory effect of silibinin on compound 48/80-induced histamine release from RPMC is concentration-dependent. The release of histamine and other inflammatory mediators from mast cells is known to play an important role in acute inflammatory processes such as anaphylaxis. ${ }^{10)}$ Therefore, these observations suggest that silibinin attenuates mast cell-mediated anaphylactoid reactions by blocking histamine release from RPMC. Tasaka et al. reported that compound 48/80 increases the permeability of the lipid bilayer membrane of mast cells by causing the perturbation of the membrane. ${ }^{28)}$ This indicates that the membrane permeability increase may be an essential trigger for the release of mediators from mast cells. Accordingly, it is reasonable to presume that silibinin inhibits histamine release by attenuating the permeability of the RPMC membrane via preventing the compound 48/80induced perturbation of the membrane. However, there is no evidence to support this assumption in the present study. Future work should address the mechanism by which silibinin reduces compound 48/80-induced histamine release.

PSA and PCA represent models of acute allergic reactions in which mast cells appear to be essential. ${ }^{29)}$ In these models, $\operatorname{IgE}$ of defined allergen specificity is injected into the caudal vein or skin, and $24 \mathrm{~h}$ thereafter, the specific antigen is administered intravenously. The ensuing FceRI aggregation of mast cells results in the secretion of multiple preformed mediators. These products in turn produce the systemic effects such as cardiopulmonary changes and death as well as the local effects including increased cutaneous blood flow, enhanced vascular permeability leading to tissue swelling and itching due to the stimulation of cutaneous sensory nerves by histamine. ${ }^{19)}$ Our results have shown that physiological responses associated with PSA and PCA are less severe in silibinin-treated mice. In addition, silibinin can inhibit the release of preformed mediators (histamine) from RPMC trig- gered by IgE. Thus, we suggest that silibinin inhibits IgEmediated anaphylaxis by down-regulating mast cell activation.

Previously, several researchers examined the effect of a variety of flavonoids on mast cell degranulation. ${ }^{30,31)}$ Although different types of cells were used in the various experimental conditions, it was shown that luteolin, baicalein, quercetin, kaempferol or myricetin significantly inhibits IgE-mediated histamine release and cytokine production from mast cells at $100 \mu \mathrm{M}$. Likewise, our result has revealed that silibinin exhibits significant inhibitory potency on histamine release and cytokine secretion at the same concentration. However, to compare the efficacy of silibinin with others, it is considered that experiments should be carried out using the same types of cells and stimuli.

Our study has demonstrated that silibinin inhibits the immunologic release of TNF- $\alpha$ and IL- 6 from RPMC. Pro-inflammatory cytokines, particularly TNF- $\alpha$ and IL-6, are known to play a central biological role in triggering and sustaining allergic inflammation in mast cells. TNF- $\alpha$ is a key mediator in many cytokine-dependent inflammatory events. It induces chemotaxis of neutrophils and $\mathrm{T}$ cells, enhances the cytotoxicity of macrophages and stimulates the expression of adhesion molecules from endothelial cells. ${ }^{32)}$ TNF- $\alpha$ is also responsible for eosinophil survival through partial inhibition of apoptosis, thereby contributes to chronic inflammation. ${ }^{33)}$ IL-6 is one of the most important mediators of fever and acute phase response, and is secreted mainly by $\mathrm{T}$ cells, macrophages and mast cells. ${ }^{34)}$ Moreover, its local accumulation is associated with a PCA reaction. ${ }^{35)}$ These reports indicate that reduction of these cytokines is one of the key indicators of attenuated allergic symptom. Thus, silibinin might affect the acute allergic reaction as well as chronic inflammation through the regulation of cytokines generation in mast cells.

To gain insight into the mechanism of mast cell inhibition by silibinin, we investigated its effect on calcium signaling, $\mathrm{NF}-\kappa \mathrm{B}$ activation and cAMP level in mast cells. Increased intracellular calcium concentration is critical for mast cell degranulation. ${ }^{36,37)}$ Intracellular calcium response after immunological stimulation is supposed to occur in (at least) two steps: first one is calcium release from the intracellular store, and second one is calcium influx from the external environment, and the latter one is considered to be essential step for FceRI-induced degranulation. ${ }^{38)}$ Thus, we measured calcium uptake using radiotracer assay. As expected from inhibition of degranulation and cytokine production by silibinin, silibinin markedly inhibits antigen-evoked calcium influx into RPMC. From this, it is inferred that silibinin inhibits mediator release through suppressing calcium uptake into mast cells.

Previous reports have demonstrated that NF- $\kappa$ B plays a critical role in immune and inflammatory responses, including asthma and anaphylaxis. ${ }^{39)}$ Activation of NF- $\kappa \mathrm{B}$ has also been observed after FceRI-mediated allergic response in mast cells. ${ }^{40)}$ Determination of NF- $\kappa \mathrm{B}$ protein level in nuclear extracts has revealed that this protein level is substantially increased in IgE-mediated mast cell activation, suggesting that $\mathrm{NF}-\kappa \mathrm{B}$ is activated. The pretreatment of silibinin results in the reduction of nuclear NF- $\kappa \mathrm{B}$ level as well as production of cytokines. Because it is known that cytokine pro- 
duction is regulated through NF- $\kappa \mathrm{B}$ expression, ${ }^{41)}$ our findings strongly suggest that silibinin reduces cytokine production in allergic inflammation by inhibiting activity of NF- $\kappa$ B. Here, silibinin may prevent NF- $\kappa \mathrm{B}$ activation by either inhibiting inhibitory kappa B $(\mathrm{I} \kappa \mathrm{B})$ degradation, stimulating $\mathrm{I} \kappa \mathrm{B}$ expression, or both. Actually, many other groups reported that silibinin exerts anti-NF- $\kappa \mathrm{B}$ actions by abovementioned mechanisms in various types of cells. ${ }^{42,43)} \mathrm{Al}$ though our study does not discriminate these possibilities, the net result of each event is the sequestration of $\mathrm{NF}-\kappa \mathrm{B}$ in the cytoplasm and inhibition of the subsequent NF- $\kappa \mathrm{B}-\mathrm{de}-$ pendent mRNA transcription including cytokine production.

Early work has provided circumstantial evidence linking cAMP to inhibition of the allergic response. An increase of intracellular cAMP is believed to cause the inhibition of mediator release from mast cells in response to stimulation of IgE receptors or compound 48/80. ${ }^{44,45)}$ This increase of cAMP is known to be due to the activation of adenylate cyclase or inhibition of cAMP phosphodiesterase, and to produce its effect by reducing the amount of free cytoplasmic calcium available for activation of various enzymes. ${ }^{36,37)}$ Interestingly, treatment of silibinin increases cAMP level beyond the basal level. Although the mechanism of silibinin-induced cAMP production has not been elucidated, silibinin may activate the adenylate cyclase directly or indirectly, otherwise inhibit cAMP phosphodiesterase, which is supported by Koch et al's report that silibinin inhibits cAMP phosphodiesterase. $^{46)}$ On the other hand, Minguet et al. have documented that adenosine, by elevating cAMP levels and activating protein kinase $A$, is capable of suppressing the $N F-\kappa B$ pathway in mast cells. ${ }^{47}$ ) This finding indicates that silibinininduced cAMP increase modulates cytokine production by repressing FceRI-mediated activation of the NF- $\kappa$ B pathway. Taken together, we propose that the anti-allergic effect of silibinin is associated with an elevation of cAMP in mast cells.

However, we cannot formally rule out the possibility that cAMP is unlikely to be important as an initiator of the secretory response in mast cells. In a few studies utilizing RPMC, it was reported that increase and decrease in cAMP were not always associated with inhibition and mediation of secretion, respectively. Moreover, extension of these studies to human cells revealed that cAMP was not related to the initiation of the secretory process. ${ }^{44)}$ Furthermore, our time-course study indicates that there is a partial discrepancy between the magnitude and duration of cAMP levels increased by silibinin and the extent of its inhibition of histamine release in mast cells (Figs. 3, 7). Therefore, the possibility that the increase of cAMP by silibinin may not inhibit mediator release cannot be excluded. Alternatively, it can be assumed that the modulatory effect of cAMP on mediator release depends more on the crosstalk of the activated signal transducting pathway than on the final level of cAMP. ${ }^{48)}$ Further studies are needed to clarify the precise link between the transduction signals in cellular regulation.

In conclusion, our results indicate that silibinin can inhibit mast cell-dependent anaphylaxis-like reactions in in vivo and in vitro murine models. Silibinin inhibition of pro-inflammatory mediator release from mast cells appears to be involved in suppression of calcium uptake and NF- $\kappa \mathrm{B}$ activity, as well as augmentation of intracellular cAMP level. Silibinin may therefore be suitable for the treatment of allergic and inflam- matory diseases. Further studies are needed to elucidate the possibility that silibinin may also be effective in the human mast cells and in the treatment of human allergic disorders.

Acknowledgments This study was supported by a Grant from Yanbian University Center of Medical Development. We are grateful to Professor Mie-Jae Im, Chonbuk National University Medical School for kind advice and critical reading of the manuscript.

\section{REFERENCES}

1) Flora K., Hahn M., Rosen H., Benner K., Am. J. Gastroenterol., 93, $139-143$ (1998).

2) Wellington K., Jarvis B., BioDrugs, 15, 465-489 (2001).

3) Agarwal R., Agarwal C., Ichikawa H., Singh R. P., Aggarwal B. B., Anticancer Res., 26, 4457-4498 (2006).

4) Li L. H., Wu L. J., Tashiro S., Onodera S., Uchiumi F., Ikejima T., Biol. Pharm. Bull., 29, 1096-1101 (2006).

5) Post-White J., Ladas E. J., Kelly K. M., Integr. Cancer Ther., 6, 104 109 (2007).

6) Gu M., Singh R. P., Dhanalakshmi S., Agarwal C., Agarwal R., Cancer Res., 67, 3483-3491 (2007).

7) Jiang S., Nakano Y., Rahman M. A., Yatsuzuka R., Kamei C., Biosci. Biotechnol. Biochem., 72, 660-665 (2008).

8) Alber G., Miller L., Jelsema C. L., Varin-Blank N., Metzger H., J. Biol. Chem., 266, 22613-22620 (1991).

9) Galli S. J., Gordon J. R., Wershil B. K., Curr. Opin. Immunol., 3, 865-872 (1991).

10) Petersen L. J., Mosbech H., Skov P. S., J. Allergy Clin. Immunol., 97, 672-679 (1996).

11) Ennis M., Pearce F. L., Weston P. M., Br. J. Pharmacol., 70, 329-334 (1980).

12) Graevskaya E. E., Yasutake A., Aramaki R., Rubin A. B., Arch. Toxicol., 77, 17-21 (2003).

13) Allansmith M. R., Baird R. S., Ross R. N., Barney N. P., Bloch K. J., Acta Ophthalmol. Suppl., 192, 145-153 (1989).

14) Lecomte J., Damas J., C. R. Seances Soc. Biol. Fil., 168, 1449-1451 (1974).

15) Lecomte J., Arch. Int. Pharmacodyn. Ther., 214, 165-176 (1975).

16) Miadonna A., Tedeschi A., Leggieri E., Lorini M., Froldi M., Zanussi C., Br. J. Clin. Pharmacol., 24, 747-752 (1987).

17) Breschi M. C., Martinotti E., Apostoliti F., Nieri P., Eur. J. Pharmacol., 437, 91-95 (2002)

18) Harvima R. J., Harvima I. T., Fraki J. E., Clin. Chim. Acta, 171, 247256 (1988).

19) Neel N. F., Creasy B. M., Rankin J. N., Pierce E. M., McCoy M. E., Daner R. H., Fowler J. A., Daniel J. C., Lantz C. S., Immunol. Lett., 95, 37-44 (2004).

20) Cochrane D. E., Douglas W. W., Proc. Natl. Acad. Sci. U.S.A., 71, 408-412 (1974)

21) Hachisuka H., Nomura H., Sakamoto F., Mori O., Okubo K., Sasai Y., Arch. Dermatol. Res., 280, 158-162 (1988).

22) Yoshimura T., Hamaguchi E., Usami E., Nakashima K., Kawaguchi M., Suzuki N., Okamoto Y., Nakao T., Yamazaki F., Biol. Pharm. Bull., 27, 929-931 (2004).

23) Choi Y. H., Yan G. H., Chai O. H., Lim J. M., Sung S. Y., Zhang X., Kim J. H., Choi S. H., Lee M. S., Han E. H., Kim H. T., Song C. H., Biol. Pharm. Bull., 29, 1360-1365 (2006).

24) Holmegaard S. N., Acta Endocrinol. Suppl. (Copenh.), 249, 1-47 (1982).

25) Shinmei Y., Hossen M. A., Okihara K., Sugimoto H., Yamada H., Kamei C., Int. Immunopharmacol., 4, 1431-1436 (2004).

26) Foreman J. C., Hallett M. B., Mongar J. L., Br. J. Pharmacol., 55, 283P-284P (1975).

27) Sullivan T. J., Parker K. L., Eisen S. A., Parker C. W., J. Immunol., 114, 1480-1485 (1975).

28) Tasaka K., Mio M., Okamoto M., Ann. Allergy, 56, $464-469$ (1986)

29) Kabu K., Yamasaki S., Kamimura D., Ito Y., Hasegawa A., Sato E., Kitamura H., Nishida K., Hirano T., J. Immunol., 177, 1296-1305 (2006). 
30) Kempuraj D., Madhappan B., Christodoulou S., Boucher W., Cao J., Papadopoulou N., Cetrulo C. L., Theoharides T. C., Br. J. Pharmacol., 145, 934-944 (2005).

31) Kimata M., Shichijo M., Miura T., Serizawa I., Inagaki N., Nagai H., Clin. Exp. Allergy, 30, 501-508 (2000).

32) Thomas P. S., Immunol. Cell Biol., 79, 132-140 (2001).

33) Levi-Schaffer F., Temkin V., Malamud V., Feld S., Zilberman Y., J. Immunol., 160, 5554-5562 (1998).

34) Hu Z. Q., Zhao W. H., Shimamura T., Curr. Med. Chem., 14, 3044 3050 (2007).

35) Mican J. A., Arora N., Burd P. R., Metcalfe D. D., J. Allergy Clin. Immunol., 90, 815-824 (1992).

36) White J. R., Ishizaka T., Ishizaka K., Sha'afi R., Proc. Natl. Acad. Sci. U.S.A., 81, 3978-3982 (1984).

37) Izushi K., Tasaka K., Immunopharmacology, 18, 177-186 (1989).

38) Janiszewski J., Huizinga J. D., Blennerhassett M. G., Can. J. Physiol. Pharmacol., 70, 1-7 (1992).
39) Siebenlist U., Franzoso G., Brown K., Annu. Rev. Cell Biol., 10, 405455 (1994).

40) Klemm S., Ruland J., Immunobiology, 211, 815-820 (2006)

41) Azzolina A., Bongiovanni A., Lampiasi N., Biochim. Biophys. Acta, 1643, 75-83 (2003).

42) Tai K. Y., Shieh Y. S., Lee C. S., Shiah S. G., Wu C. W., Oncogene, 27, 4044-4055 (2008)

43) Polyak S. J., Morishima C., Shuhart M. C., Wang C. C., Liu Y., Lee D. Y., Gastroenterology, 132, 1925-1936 (2007).

44) Weston M. C., Peachell P. T., Gen. Pharmacol., 31, 715-719 (1998).

45) Kaliner M., Austen K. F., J. Immunol., 112, $664-674$ (1974).

46) Koch H. P., Bachner J., Loffler E., Methods Find. Exp. Clin. Pharmacol., 7, 409-413 (1985).

47) Minguet S., Huber M., Rosenkranz L., Schamel W. W., Reth M., Brummer T., Eur. J. Immunol., 35, 31-41 (2005).

48) Alfonso A., Cabado A. G., Vieytes M. R., Botana L. M., Cell. Signal., 12, 343-350 (2000). 